University of Nebraska - Lincoln

DigitalCommons@University of Nebraska - Lincoln

Faculty Publications: Department of

Entomology

Entomology, Department of

February 2000

\title{
Larval Susceptibility of an Insecticide-Resistant Western Corn Rootworm (Coleoptera: Chrysomelidae) Population to Soil Insecticides: Laboratory Bioassays, Assays of Detoxification Enzymes, and Field Performance
}

\author{
Robert J. Wright \\ University of Nebraska-Lincoln, rwright2@unl.edu \\ Michael E. Scharf \\ University of Nebraska-Lincoln \\ Lance J. Meinke \\ University of Nebraska-Lincoln, Imeinke1@unl.edu \\ Xuguo Zhou \\ University of Nebraska-Lincoln \\ Blair D. Siegfried \\ University of Nebraska-Lincoln, bsiegfried1@ufl.edu

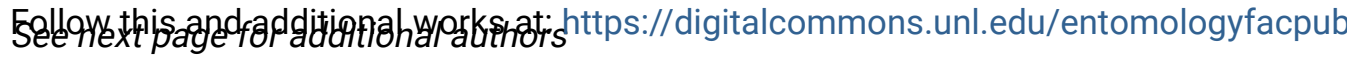 \\ Part of the Entomology Commons
}

Wright, Robert J.; Scharf, Michael E.; Meinke, Lance J.; Zhou, Xuguo; Siegfried, Blair D.; and Chandler, Laurence D., "Larval Susceptibility of an Insecticide-Resistant Western Corn Rootworm (Coleoptera: Chrysomelidae) Population to Soil Insecticides: Laboratory Bioassays, Assays of Detoxification Enzymes, and Field Performance" (2000). Faculty Publications: Department of Entomology. 37.

https://digitalcommons.unl.edu/entomologyfacpub/37

This Article is brought to you for free and open access by the Entomology, Department of at DigitalCommons@University of Nebraska - Lincoln. It has been accepted for inclusion in Faculty Publications: Department of Entomology by an authorized administrator of DigitalCommons@University of Nebraska - Lincoln. 


\section{Authors}

Robert J. Wright, Michael E. Scharf, Lance J. Meinke, Xuguo Zhou, Blair D. Siegfried, and Laurence D. Chandler 


\title{
Larval Susceptibility of an Insecticide-Resistant Western Corn Rootworm (Coleoptera: Chrysomelidae) Population to Soil Insecticides: Laboratory Bioassays, Assays of Detoxification Enzymes, and Field Performance
}

\author{
ROBERT J. WRIGHT, ${ }^{1}$ MICHAEL E. SCHARF, LANCE J. MEINKE, XUGUO ZHOU, \\ BLAIR D. SIEGFRIED, AND LAURENCE D. CHANDLER ${ }^{2}$
}

Department of Entomology, University of Nebraska-Lincoln, Lincoln, NE 68583-0816

\begin{abstract}
J. Econ. Entomol. 93(1): 7-13 (2000)
ABSTRACT Soil insecticides were evaluated in laboratory and field studies against larvae of an insecticide resistant population (Phelps County, NE) of western corn rootworm, Diabrotica virgifera virgifera LeConte. Insecticide toxicity was evaluated by topical application of technical insecticides to 3rd instars from Saunders County, NE (susceptible) and Phelps County populations. Resistance ratios $\left(\mathrm{LD}_{50}\right.$ Phelps County/ $\mathrm{LD}_{50}$ Saunders County) for the insecticides methyl parathion, tefluthrin, carbofuran, terbufos, and chlorpyrifos were 28.0, 9.3, 8.7, 2.6 and 1.3, respectively. Biochemical investigation of suspected enzymatic resistance mechanisms in 3rd instars identified significant elevation of esterase activity (alpha and beta naphthyl acetate hydrolysis [3.8- and 3.9-fold]). Examination of 3rd instar esterases by native PAGE identified increased intensity of several isoenzymes in the resistant population. Assays of cytochrome $\mathrm{P}_{450}$ activity (4-CNMA demethylation and aldrin epoxidation) did not identify elevated activity in resistant 3 rd instars. Granular soil insecticides were applied at planting to corn, Zea mays L., in replicated field trials in 1997 and 1998 at the same Phelps County site as the source of resistant rootworms for the laboratory studies. In 1997, planting time applications of Counter 20CR, Counter $15 \mathrm{G}$ (terbufos), and Lorsban $15 \mathrm{G}$ (chlorpyrifos) resulted in the lowest root injury ratings (1-6 Iowa scale); $2.50,2.55,2.65$, respectively (untreated check root rating of 4.55). In 1998, all insecticides performed similarly against a lower rootworm density (untreated check root rating of 3.72). These studies suggest that resistance previously documented in adults also is present in 3rd instars, esterases are possibly involved as resistance mechanisms, and resistance to methyl parathion in adults is also evident in larvae, but does not confer cross-resistance in larvae to all organophosphate insecticides.
\end{abstract}

KEY WORDS Diabrotica virgifera virgifera, insecticide resistance, corn

Conn ROOTwORMS (Diabrotica spp.) are a major insect pest of continuous corn, Zea mays L., in the midwestern United States. It is estimated that $50-60 \%$ of the total corn acreage in the United States is treated annually with soil insecticides for corn rootworm control (Levine and Oloumi-Sadeghi 1991). Recently, populations of western corn rootworm, Diabrotica virgifera virgifera LeConte, in parts of the midwestern United States have adapted to the traditional management strategies of crop rotation and insecticide use. An apparent shift in adult western corn rootworm behavior has occurred in portions of Illinois and Indiana, resulting in significant levels of oviposition in soybeans and failure of rotation with soybeans as a management strategy (Levine and Oloumi-Sadeghi 1996, Sammons

\footnotetext{
This article reports the results of research only. Mention of a proprietary product does not constitute an endorsement or a recommendation by USDA for its use.

${ }^{1}$ University of Nebraska, South Central Research and Extension Center, Box 66, Clay Center, NE 68933.

${ }^{2}$ Northern Grain Insects Research Laboratory, USDA-ARS, 2923 Medary Avenue, Brookings, SD 57006.
}

et al. 1997). More recently, we have documented populations of adult western corn rootworms in Nebraska with resistance to methyl parathion and carbaryl insecticides (Meinke et al. 1998), resulting in field reports of insecticide failures. Resistance has been documented in Nebraska in areas where adult management (Meinke 1995) (use of foliar insecticides to control adult populations before oviposition occurs) has been practiced for many years.

Dosage-mortality bioassays of Nebraska populations of western corn rootworms have indicated that significant levels of resistance to methyl parathion and carbaryl insecticides in adults exists, with the highest frequency and levels being centered around York and Phelps counties in south central Nebraska (Meinke et al. 1998). The distribution of adult resistance is associated with reports of control failures in the field. Synergism bioassays of adult western corn rootworms using oxidative (piperonyl butoxide) and hydrolytic (S,S,S-tributyl phosphorotrithioate) detoxification enzyme inhibitors have suggested an involvement of these enzyme classes in resistance to both methyl 
parathion (Miota et al. 1998) and carbaryl (Scharf et al. 1999) for representative York and Phelps county populations. Biochemical and metabolism-based investigations of methyl parathion resistance mechanisms also have supported the likelihood that oxidation and hydrolysis are involved in York and Phelps county populations. Biochemical results also indicate insensitive acetylcholinesterase as a minor mechanism of methyl parathion resistance in Phelps County beetles.

To date, our investigations of insecticide resistance in Nebraska populations of western corn rootworm have exclusively involved adults. Two important questions that remain are: does resistance and associated mechanisms extend to larvae, and if so, does this lead to a loss in soil insecticide efficacy? Using a population from an area where adult resistance is well documented (Phelps County, NE), the objectives of these studies were as follows: (1) to examine levels of larval susceptibility to commonly used soil insecticide active ingredients, (2) to examine oxidative and hydrolytic detoxification enzymes in larvae, and (3) to evaluate performance of soil insecticides in the field.

\section{Materials and Methods}

Insect Populations. Adult western corn rootworms were collected in summer 1996 from a commercial corn field near Holdrege NE (Phelps County), and from a corn field at the University of Nebraska-Lincoln Agricultural Research \& Development Center, near Mead, NE (Saunders County), and shipped to the USDA-ARS Northern Grain Insects Research Laboratory, Brookings, SD The resistance status of these populations has been previously documented based on topical bioassay procedures against adults (Meinke et al. 1998, unpublished data). Standard procedures were used to collect and maintain eggs until termination of diapause and to rear $F_{1}$ larvae (Jackson 1986). Larvae were sent to the university for laboratory studies. The 1997 field study was conducted in the same commercial corn field in Phelps County from which beetles were collected in 1996. The 1998 field study was conducted in a different field on the same farm, $<0.5 \mathrm{~km}$ away from the 1997 site.

Topical Application Bioassays. Five technical-grade insecticides were examined (\% purity): methyl parathion (96.5\%) (Chemical Services, West Chester, PA), tefluthrin (99\%) (Zeneca, Wilmington, DE), carbofuran $(98 \%)$ (FMC, Princeton, NJ), terbufos (99\%) (American Cyanamid, Princeton, NJ), and chlorpyrifos (98\%) (DowElanco, Indianapolis, IN). Insecticide dilutions in acetone $(0.5 \mu \mathrm{l})$ (>99.5\% purity; Baxter Diagnostic S/P acetone, Deerfield, IL) were applied to the dorsal abdomen of individual 3rd instars, and control larvae were treated with $0.5 \mu$ l of acetone alone. The treated larvae were held in petri plates $(50$ by $9 \mathrm{~mm}$ ) supplied with, filter paper $(42 \mathrm{~mm}$ diameter, Whatman \#2) moistened with $200 \mathrm{ml}$ water, and sealed with Parafilm (American National Can, Neenah, WI). Mortality was scored after holding plates at $20^{\circ} \mathrm{C}$ for $24 \mathrm{~h}$ in darkness, and was assessed by an inability of larva to withdraw its head by probing with a dissecting needle. Third instars were chosen because of our ability to individually treat larvae of this size, which provided the most information from the limited number of larvae available.

For each insecticide, 4-6 concentrations were tested, causing mortality which ranged from 1 to $100 \%$. Six replicates of 10 larvae each were performed for each concentration and control, to give total sample sizes $(n)$ of $240-350$ per insecticide bioassay. Thirty randomly selected larvae were weighed per bioassay so that dose could be calculated on a body weight basis (ng insecticide/mg body weight). Dose-mortality data were analyzed by probit analysis as adapted for PC use (POLO PC) which automatically corrected for control mortality by Abbott's transformation (LeOra Software 1987). Resistance ratios were calculated for each insecticide by dividing the $\mathrm{LD}_{50}$ values of the resistant Phelps County population by those from the susceptible Saunders County population. Confidence intervals for resistance ratios were calculated by the method of Robertson and Preisler (1992), and were used to test the significance of resistance ratios at the 95\% level of confidence. With this test, if the 95\% confidence interval calculated for a ratio does not include 1.0, a significant difference exists between the values being compared (Robertson and Preisler 1992, Scharf et al. 1995).

Enzyme Preparations and Protein Assay. Third instars of the Saunders and Phelps County populations were homogenized in $1 \mathrm{ml}$ of either of the following buffers. Buffer A: $0.15 \mathrm{M}$ potassium phosphate $(\mathrm{pH}$ 7.6) containing $10 \%$ (vol:vol) glycerol, $1 \mathrm{mM}$ PMSF [phenylmethyl sufonyl flouride] (Sigma, St. Louis MO); $1 \mathrm{mM}$ PTU [phenylthiourea] (Sigma); $1 \mathrm{mM}$ EDTA [ethylene diamine tetra-acetate] (Sigma); and $0.1 \mathrm{mM}$ DTT [dithiothreitol] (Sigma) for cytochrome P450 assays. Buffer B: 0.1 M sodium phosphate $(\mathrm{pH}$ 7.8) for esterase activity assays. Buffer C: $0.1 \mathrm{M}$ sodium phosphate $+0.1 \%$ Triton $\mathrm{X}-100$ ( $\mathrm{pH} 7.8$ ) (Sigma) for esterase native PAGE. Homogenizations were performed using a Teflon glass Potter-Elvehjem type homogenizer, and homogenate was centrifuged for 20 min at $12,000 \times g$ and $4^{\circ} \mathrm{C}$. Supernatants were filtered through glass wool and used directly in assays or loaded onto gels. Protein content was estimated using a commercially available bicinchoninic acid kit (Pierce, Rockford, IL), following the manufacturer's instructions, and bovine serum albumin (Sigma) as a standard.

Cytochrome $\mathbf{P}_{450}$-Dependent Aldrin Epoxidation Assays. Aldrin epoxidation activity was measured by quantifying the conversion of aldrin to its epoxide, dieldrin (Siegfried and Mullin 1988). The 0.5-ml incubation mixture (with final concentrations) in $0.1 \mathrm{M}$ potassium phosphate buffer, $\mathrm{pH}$ 7.4, included aldrin (>99\% purity, Crescent Chemical, Hauppage, NY) $(0.05 \mathrm{mM})$ introduced in $5 \mu \mathrm{l}$ ethanol, NADPH [nicotinamide adenine dinucleotide phosphate] (reduced form) (Sigma) $(1.0 \mathrm{mM})$ and $100 \mu \mathrm{l}$ of $12,000 \times g$ supernatant. After a 1 -min preincubation at $31^{\circ} \mathrm{C}$, NADPH was added and the reaction proceeded for 
20 min with shaking. A combined 2,2,4-trimethylpentane extract $(2$ by $0.5 \mathrm{ml}$ ) of the assay mixture was dried over anhydrous sodium sulfate and analyzed with dieldrin (>99\% purity, Crescent Chemical, Hauppage, NY) standards by gas liquid chromatography. Activities based on peak areas were calculated relative to controls lacking NADPH.

Cytochrome $\mathbf{P}_{450}$-Dependent 4-CNMA Demethylation Assays. Metabolism of the model substrate 4-chloro-N-methylaniline (4-CNMA; Aldrich, Milwaukee, WI) was initiated by combining $50 \mu \mathrm{l}$ of $12,000 \times \mathrm{g}$ supernatant and $250 \mu \mathrm{l}$ of demethylation assay reaction mixture [Tris- $\mathrm{HCl}(0.4 \mathrm{M}, \mathrm{pH} 7.5)$, NADPH (1.8 mM), 4-CNMA (1.5 mM) in ethanol (20\% vol:vol), and Tween-20 (EIA grade; Bio-Rad, Hercules, CA) at a volume equivalent to that of substrate in ethanol] (Kupfer and Bruggerman 1966). Blank reactions contained all components except that an equivalent volume of Tris-HCl was substituted for NADPH. The reaction proceeded for $15 \mathrm{~min}$ with shaking at $37^{\circ} \mathrm{C}$, and was terminated by adding $375 \mu \mathrm{l}$ of demethylation assay stop solution [p-dimethyl-aminobenzaldehyde $(15 \mathrm{mg} / \mathrm{ml})$ in $1.0 \mathrm{~N}$ sulfuric acid]. Microcentrifuge tubes containing the stopped reaction were centrifuged for $15 \mathrm{~min}$ at $12,000 \times g$ and $4^{\circ} \mathrm{C}$. The product, 4-chloroaniline, was quantified by comparing absorbance of supernatants at $445 \mathrm{~nm}$ to simultaneously determined standard curves $(0-50(\mu \mathrm{mol})$ in a DU-65 spectrophotometer (Beckman, Palo Alto, CA).

Naphthyl Acetate Esterase Assays. Nonspecific esterase activity was assayed by quantifying the production of $\alpha$ or $\beta$ naphthol (Sigma) from the substrates $\alpha$ or $\beta$ naphthyl acetate (Sigma) using the general method of Van Asperen (1962). Reaction mixtures consisted of $10 \mu \mathrm{l}$ of $12,000 \times g$ supernatant, $2 \mu \mathrm{l}$ substrate solution in acetone $(25.0 \mathrm{mM})$ and $188 \mu \mathrm{l}$ buffer B. Reactions proceeded in microplate wells for $15 \mathrm{~min}$ at $30^{\circ} \mathrm{C}$ and were terminated by the addition of $33 \mathrm{ml}$ of $0.3 \%$ (wt:vol) Diazo blue B (Sigma) in 3.5\% (wt:vol) sodium lauryl sulfate. After allowing color to develop for $15 \mathrm{~min}$, absorbance was measured at 600 $\mathrm{nm}$ in a microplate reader (Bio-Tek, Winooski, VT), and the concentration of hydrolyzed substrate was calculated from standard curves of $\alpha$ or $\beta$ naphthol.

Native PAGE. Nondenaturing polyacrylamide gel electrophoresis (Native PAGE) was performed in a vertical electrophoresis unit (Bio-Rad Protean II, Richmond, CA) using an 8\% (acrylamide) separating gel and $4 \%$ stacking gel with a discontinuous Trisglycine buffer system. Samples of $12,000 \cdot g$ supernatant prepared in buffer $\mathrm{C}$ were diluted $1: 1$ with $50 \mathrm{mM}$ Tris-glycine buffer (pH 8.3) containing $20 \%$ sucrose (wt:vol). Individual wells were loaded with a volume of enzyme extract containing $5 \mu \mathrm{g}$ protein; $0.1 \%$ Bromophenol Blue in $10 \%$ sucrose was used as a marker in each gel. Gels were run at $120 \mathrm{~V}$ for $1 \mathrm{~h}$ at $4^{\circ} \mathrm{C}$. Esterase bands were visualized by incubating the gels in $49 \mathrm{ml}$ of a staining solution consisting of $0.02 \mathrm{M}$ sodium phosphate buffer ( $\mathrm{pH}$ 7.0), $20 \mathrm{mg}$ Fast Garnet GBC salt (Sigma), and $1 \mathrm{ml}$ of $30 \mathrm{mM} \alpha$ or $\beta$ naphthyl acetate in acetone.
Field Evaluation of Soil Insecticides. In 1997 and 1998, replicated studies were conducted at the Phelps County site to evaluate labeled granular insecticides applied at planting at a site documented to have resistant adult rootworms. The 1997 trial was established in a field with a high population of adults in the summer of 1996. Rootworms at this site were $100 \%$ western corn rootworm. Experimental design was a randomized complete block (RCB) with 4 replicates. Each plot consisted of a single row $9.1 \mathrm{~m}$ long with a $76.2-\mathrm{cm}$ row spacing planted with 'Golden Harvest 2547' hybrid (Golden Harvest Seeds, Waterloo, NE) on 24 April 1997 and with 'Golden Harvest 2581' hybrid on 24 April 1998. Granular insecticides-terbufos (Counter 20CR, Counter 15 G, American Cyanamid, Parsippany, NJ); chlorpyrifos (Lorsban 15 G, Dow Agrosciences, Indianapolis, IN); tebupirimfos + cyfluthrin (Aztec 2.1 G, Bayer, Kansas City, MO); fonofos (Dyfonate $15 \mathrm{G}$, Zeneca Ag Products, Wilmington, DE); chlorethoxyphos (Fortress $2.5 \mathrm{G}$, Fortress $5 \mathrm{G}$, DuPont, Wilmington, DE); tefluthrin (Force $3 \mathrm{G}$, Zeneca, Wilmington, DE) - were applied either directed into the open seed furrow (infurrow), or as a $18-\mathrm{cm}$ band in front of the planter-press wheel, over the open seed furrow and incorporated with the press wheel (T-band). Additional details of the field conditions, and experimental procedures are described in DeVries et al. (1998). After most of the larval feeding had occurred (23 July 1997, 7 July 1998), 5 plants were dug from each plot, and roots were washed and rated for rootworm injury using the Iowa 1-6 root injury scale (1, no feeding; 6,3 or more root nodes completely destroyed) (Hills and Peters 1971). Insecticide efficacy was evaluated based on root injury ratings and the percentage of plants rated 3 or less on the 1-6 scale (percentage consistency). Percentage consistency data were converted using the angular transformation before analysis. Efficacy data were analyzed by analysis of variance (ANOVA) for randomized complete block design, with mean separation by Ryan $Q$ test $(P=0.05)$ (SAS Institute 1985).

\section{Results}

Insecticide Bioassays. At the $\mathrm{LD}_{50}$ level, significant differences in resistance ratios $(P<0.05)$ were observed in the Phelps County population to all insecticides examined (Table 1 ). $\mathrm{LD}_{90}$ resistance ratios were very similar to those at $\mathrm{LD}_{50}$, which is a direct result of the similarities in slope between the resistant and susceptible populations (Table 1 ). All $\mathrm{LD}_{90}$ resistance ratios also were significant $(P<0.05)$, with the exception of the O-ethyl-substituted organophosphate terbufos. The highest resistance ratio observed was to the O-methyl-substituted organophosphate methyl parathion $\left(\mathrm{LD}_{50}\right.$ resistance ratio $\left.=28.0\right)$. Lower resistance ratios (i.e., $<3$-fold) were observed with 2 O-ethyl-substituted organophosphates (terbufos and chlorpyrifos).

Enzyme Activity Assays and Native PAGE. Enzyme activity assays were conducted to quantify the specific activity of suspected enzymatic resistance mecha- 
Table 1. Insecticide toxicity to larval D. virgifera virgifera as assessed by lethal-dose bioassays, for susceptible (Saunders County) and resistant (Phelps County) Nebraska populations

\begin{tabular}{|c|c|c|c|c|c|c|c|c|}
\hline Insecticide & Population & $n^{a}$ & $\chi^{2 b}$ & $\begin{array}{l}\text { Slope } \\
( \pm \mathrm{SE})\end{array}$ & $\mathrm{LD}_{50}(95 \% \mathrm{CI})^{c}$ & $\mathrm{RR}_{50}{ }^{d}$ & $\mathrm{LD}_{90}(95 \% \mathrm{CI})^{c}$ & $\mathrm{RR}_{90}{ }^{d}$ \\
\hline \multirow[t]{2}{*}{ Methyl Parathion } & Saunders (S) & 347 & 7.0 & $2.7(0.3)$ & $2.93(1.19-4.45)$ & - & $8.60(5.57-25.76)$ & - \\
\hline & Phelps (R) & 352 & 6.9 & $2.4(0.3)$ & $84.37(45.63-124.28)$ & $28.0^{*}$ & $286.93(184.10-800.49)$ & $31.9 *$ \\
\hline \multirow[t]{2}{*}{ Terbufos } & Saunders (S) & 297 & 1.3 & $2.1(0.3)$ & $4.95(3.49-6.44)$ & - & $19.57(14.15-33.30)$ & - \\
\hline & Phelps (R) & 298 & 1.2 & $2.5(0.3)$ & $12.62(9.11-16.09)$ & $2.6^{*}$ & $40.85(31.62-58.64)$ & 2.1 \\
\hline \multirow[t]{2}{*}{ Chlorpyrifos } & Saunders (S) & 239 & 0.4 & $3.4(0.6)$ & $3.16(2.37-3.89)$ & - & $7.63(6.07-11.00)$ & - \\
\hline & Phelps (R) & 241 & 1.1 & $2.8(0.4)$ & $3.92(2.98-4.90)$ & $1.3^{*}$ & $11.30(8.71-16.54)$ & $1.4^{*}$ \\
\hline \multirow[t]{2}{*}{ Carbofuran } & Saunders (S) & 347 & 5.8 & $1.9(0.4)$ & $0.73(0.16-1.33)$ & - & $3.37(1.82-20.02)$ & - \\
\hline & Phelps (R) & 298 & 9.2 & $2.1(0.2)$ & $6.37(2.79-12.27)$ & $8.7^{*}$ & $25.15(12.91-143.4)$ & $7.5^{*}$ \\
\hline \multirow[t]{2}{*}{ Tefluthrin } & Saunders (S) & 350 & 4.1 & $2.0(0.3)$ & $2.55(1.53-3.61)$ & - & $8.44(5.97-14.05)$ & - \\
\hline & Phelps (R) & 350 & 7.3 & $3.4(0.8)$ & $23.71(14.61-34.40)$ & $9.3^{*}$ & $78.34(52.72-144.79)$ & $9.3^{*}$ \\
\hline
\end{tabular}

\footnotetext{
${ }^{a}$ Number of insects on which each probit analysis is based.

${ }^{b}$ Chi-square values obtained from POLO-PC output, indicating goodness-of-fit of the crude mortality data.

${ }^{c}$ Lethal doses of insecticide in ng insecticide per milligram body weight.

${ }^{d}$ Resistance ratios indicating the difference for Phelps County $(\mathrm{R})$ over Saunders County $(\mathrm{S})$ populations at $\mathrm{LD}_{50}$ and $\mathrm{LD}_{90}$.

*, Significant differences in LD values being compared $(P<0.05$; Robertson and Preisler 1992).
}

nisms toward model substrates (Table 2). Cytochrome $\mathrm{P}_{450}$-mediated aldrin epoxidation and 4-CNMA. Ndemethylation activity were significantly reduced $(t=$ 2.11 , $\mathrm{df}=17, P<0.05)$ and nonsignificantly elevated $(t=2.13, \mathrm{df}=15, P>0.05)$, respectively, in the resistant Phelps County population. Nonspecific esterase-mediated metabolism of the model substrates ( $\alpha$ and $\beta$ naphthyl acetate indicated significant $(t=$ $1.98, \mathrm{df}=102, P<0.05$ for both) elevations in activity by these enzymes (3.8- and 3.9-fold, respectively). Results of native PAGE of $12,000 \times g$ supernatants, incubated with either $\alpha$ or $\beta$ naphthyl acetate, confirm results of esterase activity assays (Fig. 1). Elevated activity of 3 isozymes was observed in the Phelps County population; however, no substantial differences in staining intensity were apparent between the 2 substrates.

Field Evaluation of Soil Insecticides. In 1997, there was relatively high rootworm pressure at the Holdrege site; the untreated plots averaged 4.55 on the $1-6$ scale (Table 3). Although the relationship between root injury ratings and yield is quite variable, ratings of $>3$ suggest the potential for economic loss (Mayo 1986; see also Gray and Steffey 1998). Based on root injury ratings, all insecticides significantly reduced root injury compared with the untreated control. However, based on percentage consistency of root ratings Force $3 \mathrm{G}$ was not significantly different than the untreated check. Three insecticides applied at planting (Counter 15 G, 20CR, and Lorsban 15 G) provided statistically similar levels of root protection (all with root injury ratings of $<3$ ), had $95 \%$ consistency of root ratings and were the best treatments in 1997 (Table 3). The active ingredients of these products (Counter $15 \mathrm{G}$ and 20CR; terbufos, Lorsban $15 \mathrm{G}$; chlorpyrifos) are both ethyl-substituted organophosphate insecticides.

There was lower rootworm pressure (untreated controls averaged 3.72) in 1998 compared with 1997 (Table 3). Under these conditions, all granular insecticides provided significantly lower root injury ratings and higher percentage consistency values than the untreated control, with no significant differences among the treatments.

\section{Discussion}

Insecticide Toxicity, Enzyme Activity, and Native PAGE. Results of all laboratory investigations agree with previous results obtained for Phelps County adults. The Phelps County population examined here began experiencing field-control failures following $>10 \mathrm{yr}$ of adult exposure to an encapsulated methyl parathion formulation (Wright et al. 1996). Methyl parathion resistance was subsequently documented in Phelps County adults using topical applications (16.4fold resistance; Meinke et al. 1998), and lethal con-

Table 2. Biochemical assays of cytochrome $P_{450}$ and esterase activities from 3 rd instars of insecticide-susceptible and resistant western corn rootworm populations

\begin{tabular}{|c|c|c|c|c|}
\hline \multirow{3}{*}{ Population } & \multicolumn{4}{|c|}{ Enzyme activity $/ \mathrm{min} / \mathrm{mg}$ protein $( \pm \mathrm{SE})^{a}$} \\
\hline & \multicolumn{2}{|c|}{ Cytochrome $\mathrm{P}_{450}$ monooxygenase } & \multicolumn{2}{|c|}{ Esterase } \\
\hline & Aldrin epoxidation & 4-CNMA demethylation & $\alpha$ NA hydrolysis & $\beta$ NA hydrolysis \\
\hline Saunders County (S) & $3.22(0.57)$ & $176.50(80.80)$ & $175.51(12.00)$ & $160.12(11.51)$ \\
\hline Phelps County (R) & $1.77(0.32)$ & $301.97(6.63)$ & $663.65(43.75)$ & $619.36(41.80)$ \\
\hline $\mathrm{R} / \mathrm{S}^{b}$ & $0.5^{*}$ & 1.7 & $3.8^{*}$ & $3.9^{*}$ \\
\hline
\end{tabular}

\footnotetext{
${ }^{a}$ Enzyme activity per min per mg protein based on metabolism of the model substrates: aldrin (aldrin; pmol), 4-CNMA (4-chloro-Nmethylaniline; nmol), $\alpha$ NA (alpha naphthyl acetate; nmol) and $\beta$ NA (beta naphthyl acetate; nmol).

${ }^{b}$ Ratios of Phelps County (R) to Saunders County (S) enzyme activity.

*, Significantly different by paired $t$-tests $(P<0.05, n=6-10$ replicates $)$. Aldrin epoxidation: $t=2.11$, df $=17,4$-CNMA demethylation; $t=2.13, \mathrm{df}=15, \alpha-\mathrm{NA}: t=1.98, \mathrm{df}=102, \beta-\mathrm{NA}: t=1.98, \mathrm{df}=102$.
} 


\section{$\alpha$-Naphthyl Acetate Stained}

\section{Saunders

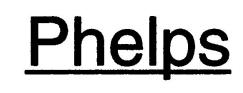

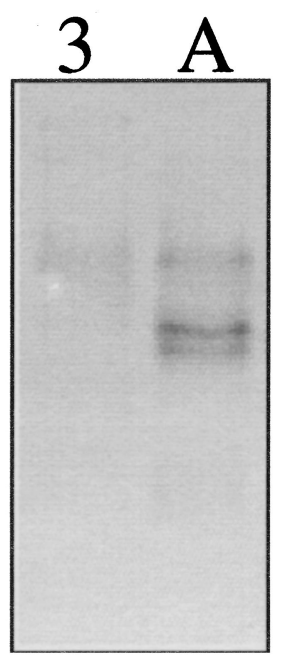

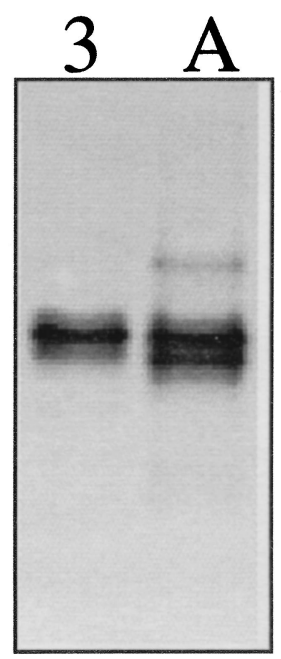

$\beta$-Naphthyl Acetate Stained
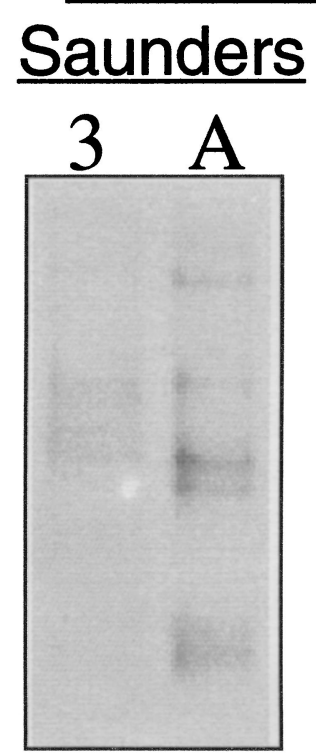

Phelps

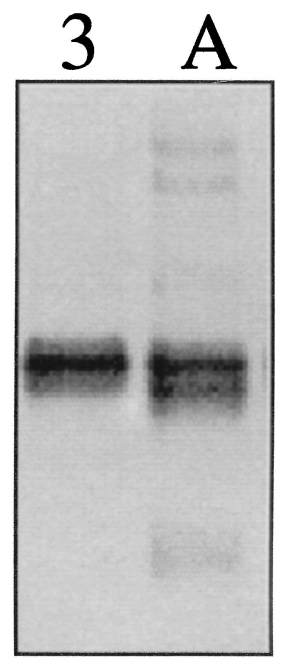

Fig. 1. Native polyacrylamide gels containing $5 \mu \mathrm{g}$ electrophoresed proteins per lane, stained for esterase activity using the substrates $\alpha$ or $\beta$ naphthyl acetate and Fast Garnet GBC salt. Esterases from the insecticide-resistant Phelps County population stained more intensely than those of the susceptible Saunders County population for either substrate. 3 , third instars; A, adults.

centration vial bioassays (25.7-fold resistance; Miota et al. 1998). Results of the current topical application-LD bioassays confirm that this resistance extends to larvae, but does not result in equal cross-resistance to other insecticides from the organophosphate, carbamate, or pyrethroid classes. Trends in topical toxicity data further indicate that O-methyl-substituted organophosphate insecticides (i.e., methyl parathion) are more highly tolerated than those which are O-ethyl-substituted (i.e., terbufos and chlorpyrifos). Similar trends suggesting higher-level resistance to O-methyl-substituted organophosphate insecticides (methyl parathion, dimethoate) also were previously noted in adult Phelps County beetles (Miota et al. 1998).

Biochemical investigations of oxidative (i.e., cytochrome $\mathrm{P}_{450}$ monooxygenases) and hydrolytic en-

Table 3. Efficacy of granular soil insecticides applied at planting against a western corn rootworm population with adult insecticide resistance, Holdrege, NE, 1997, 1998

\begin{tabular}{|c|c|c|c|c|c|c|}
\hline \multirow[t]{2}{*}{ Product } & \multirow{2}{*}{$\begin{array}{l}\text { Product rate, } \\
\mathrm{oz} / 1,000 \text { row- } \mathrm{ft}\end{array}$} & \multirow[t]{2}{*}{ Placement $^{a}$} & \multicolumn{2}{|c|}{ Root injury rating $^{b}$} & \multicolumn{2}{|c|}{$\begin{array}{c}\% \text { consistency of root } \\
\text { ratings }^{c}\end{array}$} \\
\hline & & & 1997 & 1998 & 1997 & 1998 \\
\hline Counter 20CR & 6 & $\mathrm{~TB}$ & $2.50 \mathrm{~d}$ & $2.30 \mathrm{~b}$ & $95 \mathrm{a}$ & $100 \mathrm{a}$ \\
\hline Counter 15G & 8 & $\mathrm{~TB}$ & $2.55 \mathrm{~d}$ & - & $95 \mathrm{a}$ & - \\
\hline Lorsban 15G & 8 & $\mathrm{~TB}$ & $2.65 \mathrm{~d}$ & $2.47 \mathrm{~b}$ & $95 \mathrm{a}$ & $100 \mathrm{a}$ \\
\hline Aztec $2.1 \mathrm{G}$ & 6.7 & $\mathrm{~TB}$ & $3.15 \mathrm{c}$ & $2.55 \mathrm{~b}$ & $80 \mathrm{a}$ & $100 \mathrm{a}$ \\
\hline Dyfonate 15G & 8 & $\mathrm{~TB}$ & $3.35 \mathrm{bc}$ & - & $60 \mathrm{ab}$ & - \\
\hline Fortress 5G & 3 & IF & $3.40 \mathrm{bc}$ & - & $60 \mathrm{ab}$ & - \\
\hline Fortress 2.5G & 6 & $\mathrm{IF}$ & - & $2.60 \mathrm{~b}$ & - & $97.1 \mathrm{a}$ \\
\hline Force 3G & 4 & $\mathrm{IF}$ & $3.75 b$ & - & $40 \mathrm{bc}$ & - \\
\hline Force 3G & 4 & $\mathrm{~TB}$ & - & $2.40 \mathrm{~b}$ & - & $100 \mathrm{a}$ \\
\hline Untreated & - & - & $4.55 \mathrm{a}$ & $3.55 \mathrm{a}$ & $5 \mathrm{c}$ & $55.5 \mathrm{~b}$ \\
\hline Untreated & - & - & - & $3.90 \mathrm{a}$ & - & $50.0 \mathrm{~b}$ \\
\hline
\end{tabular}

\footnotetext{
${ }^{a} \mathrm{~TB}, \mathrm{~T}$-band; IF, infurrow.

${ }^{b}$ Iowa 1-6 root rating scale (Hills and Peters 1971). Means sharing a letter in common not significantly different $(P=0.05)$, Ryans $Q$ test. 1997: $F=28.68 ; \mathrm{df}=3,7 ; P=0.001 .1998: F=19.56 ; \mathrm{df}=3,6 ; P=0.001$.

${ }^{c}(\%$ of roots $\leq 3)$. Data converted by angular transformation before ANOVA; data shown are original percentages. Means sharing a letter in common not significantly different $(P=0.05)$, Ryans $Q$ test. $1997: F=13.30 ; \mathrm{df}=3,7 ; P=0.001 .1998: F=6.34 ; \mathrm{df}=3,6 ; P=0.01$.
} 
zymes (i.e., esterases) identified significant elevation of only hydrolytic enzymes. Oxidative enzyme activities in larvae showed different patterns than those noted earlier for adults (Miota et al. 1998). Specifically, adult aldrin epoxidase activity was nonsignificantly increased 1.5-fold over the susceptible Saunders County population in the Phelps County population, whereas there was nonsignificantly reduced 4-CNMA demethylation activity. Results for larvae indicate a significant 0.5 -fold decrease in aldrin epoxidase activity, but a nonsignificant increase in 4-CNMA demethylation activity. At the present time, it is not possible to identify the roles, if any, of these differences in cytochrome $\mathrm{P}_{450}$ enzyme activity on the observed resistance.

Hydrolytic enzyme activity in larvae was elevated toward both $\alpha$ and $\beta$ naptholic esters, as previously observed for adults (Miota et al. 1998). Additionally, native PAGE identified 3 isozymes which were more intense in the Phelps County than susceptible Saunders County larvae, and are assumed to be responsible for the elevation of in vitro activity. Larval esteraseisozyme patterns also were similar to those noted here and earlier for adults, which also were shown to be interacting with the bioactive metabolite methyl paraoxon rather than the parent thiophosphate, parathion (Miota et al. 1998).

We assume methyl parathion-selection pressure on larvae to be virtually nonexistent (there are no commercial products labeled for soil application with this active ingredient); therefore, it is likely that the same resistance-conferring mechanisms are implicated in larvae and adults. Currently, esterases have been identified as the most consistent factor between the 2 life stages. However, other stage-dependent physiological factors cannot be excluded as mechanisms in the 1.7fold increase in resistance levels of 3rd instars in comparison with adults (Phelps County larval $\mathrm{RR}_{50} ; 28.0$ [Table 1]: Phelps County adult $\mathrm{RR}_{50} ; 16.4$, [Meinke et al. 1998]). For example, cytochrome $\mathrm{P}_{450}$-dependent aldrin epoxidase activity was previously observed to be elevated 6.4-fold in fed adults in comparison with 3rd instar western corn rootworms (Siegfried and Mullin 1988). If an accompanying reduction in cytochrome $\mathrm{P}_{450}$-dependent bioactivation of methyl parathion to methyl paraoxon (Miota et al. 1998) were associated with this decrease in oxidative activity, a corresponding increase in tolerance could result.

Field Trial. In general the results of the 1997 field study (Table 3) were similar to the results of the laboratory topical application study (Table 1); planting time applications of Counter $15 \mathrm{G}$, Counter 20CR, and Lorsban $15 \mathrm{G}$ resulted in the lowest root injury ratings, and Force $3 \mathrm{G}$ resulted in significantly higher root injury ratings, but all had root injury ratings significantly better than the untreated control. Based on root ratings, Aztec 2.1 G, Fortress 5 G, and Dyfonate $15 \mathrm{G}$ also performed significantly better than the untreated control and were significantly less effective than Counter 15 G, 20CR, or Lorsban 15 G, but were not evaluated in laboratory studies. However, field performance of soil insecticides is influenced by many variables in addition to insect susceptibility (e.g., application timing, temperature and moisture, soil type, calibration, rootworm population pressure, microbial degradation) (Levine and Oloumi-Sadeghi 1991). The 1998 field results (Table 3) show that under lower rootworm pressure, all the products tested provided equivalent and commercially acceptable levels of root protection.

Previous studies have used soil bioassays against newly hatched 1st instars to assess larval susceptibility to soil insecticides (Chio et al. 1978, Sutter 1982, Monke et al. 1985, Monke and Mayo 1990). We chose to use a topical bioassay against 3rd instars to make maximal use of a limited number of larvae, to reduce labor and time needed to conduct bioassays, and to avoid variability caused by soil texture and soil moisture influences. It is interesting that a topical bioassay of 3rd instars using technical-grade insecticide provides similar results to a field study. Soil insecticides applied as formulated products at planting exert toxicity on early-instar rootworm larvae. The similar response in laboratory and field studies suggests the possibility that larval resistance mechanisms are not age-specific.

Management Implications. In areas of Nebraska where resistance to methyl parathion or carbaryl in the adult stage has been documented (Meinke et al. 1998, Scharf et al. 1999), growers have 2 general management options: crop rotation or use of insecticides targeted at adult or larval stages (Meinke 1995). Crop rotation is the primary nonchemical control option currently available, and has the benefit of reducing selection pressure for insecticide resistance. The results of these studies are significant in that they document that some organophosphate insecticides (terbufos and chlorpyrifos) are still highly effective when used as planting time treatments against methyl parathion-resistant larval corn rootworms. Other commercially available granular insecticides applied at planting provided acceptable levels of root protection against the lower rootworm population in 1998. However, based on results of our laboratory and field studies, the possibility exists for reduced control against resistant larval populations, especially in situations with high rootworm densities.

In continuous corn, use of soil insecticides when the economic threshold is exceeded may have some advantages over adult control from a resistance management perspective because only a portion of the field is treated (planting time insecticides are applied infurrow or as an 18-cm band). Because of this, some larvae are able to survive on roots outside of the treated area. Previous research (Sutter et al. 1991) has shown that depending on the insecticide and environmental conditions (particularly soil moisture), adult emergence may be reduced $16-81 \%$ by planting time soil applications compared with an untreated control. Thus, soil insecticides may provide a withinfield refuge that allows survival of a variable percentage of unselected rootworms, and maintenance of susceptible alleles in a population. 
Because both adults and larvae exhibited elevated levels of esterases in resistant populations, selection of one life stage may have an impact on resistance expressed in another stage. For example, even where crop rotation is the primary control strategy for corn rootworms, foliar insecticides (e.g., methyl parathion) used against other pests (e.g., European corn borer [Ostrinia nubilalis Hübner]) during the period of adult rootworm activity (late July-August) may influence future resistance levels of adult and larval rootworms. We speculate that this may have played a role in the development of resistance in the York County populations (Meinke et al. 1998), where adult corn rootworm control has not been used as frequently as in Phelps County, but historically has commonly had economic populations of European corn borers. Conversely, use of $B$. $t$. transgenic corn hybrids may reduce selection pressure against rootworms by replacing use of foliar applications of insecticides previously targeted against European corn borers.

\section{Acknowledgments}

We thank Jim Brown, Terry DeVries, and Mary Reed (University of Nebraska-Lincoln) for assistance with this research and Shripat Kamble and Steve Danielson (University of Nebraska-Lincoln) for review of the manuscript. This research was supported in part by grants from Elf-Atochem, American Cyanamid Corporation, Dow Agrosciences, Bayer Corporation, Zeneca Ag Products, and FMC, and by USDAARS Specific Cooperative Agreement 58-5447-6-116. This research was supported by the USDA-ARS Northern Grain Insects Laboratory, and University of Nebraska Agricultural Experiment Station Project Nos. 17-058, 17-071, and 48-022. This is Paper No. 12422 of the Journal Series of the University of Nebraska Agricultural Research Division and Contribution No. 1008 of the Department of Entomology, University of Nebraska-Lincoln.

\section{References Cited}

Chio, H., C. Chang, R. L. Metcalf, and J. Shaw. 1978. Susceptibility of four species of Diabrotica to insecticides. J. Econ. Entomol. 71: 389-393.

DeVries, T. A., R. J. Wright, L. J. Meinke, and B. D. Siegfried. 1998. Evaluation of soil insecticides for control of larval corn rootworm, 1997. Arthropod Manage. Tests 23: 193-194.

Gray, M. E., and K. L. Steffey. 1998. Corn rootworm larval injury and root compensation of 12 maize hybrids: an assessment of the economic injury index. J. Econ. Entomol. 91: 723-740.

Hills, T. M., and D. C. Peters. 1971. A method of evaluating postplanting insecticide treatment for control of western corn rootworm larvae. J. Econ. Entomol. 64: 764-765.

Jackson, J. J. 1986. Rearing and handling of Diabrotica virgifera and Diabrotica undecimpunctata howardi, pp. 2547, In J. L. Krysan and T. A. Miller [eds.], Methods for the study of pest Diabrotica. Springer, New York.

Kupfer, D., and L. L. Bruggerman. 1966. Determination of enzymatic demethylation of p-chloro-N-methylaniline: assay of aniline and p-chloroaniline. Biochem. J. 17:505-512.

Levine, E., and H. Oloumi-Sadeghi. 1991. Management of diabroticite rootworms in corn. Annu. Rev. Entomol. 36: 229-255.
Levine, E., and H. Oloumi-Sadeghi. 1996. Western corn rootworm larval injury to corn grown for seed production following soybeans grown for seed production. J. Econ. Entomol. 89: 1010-1016.

LeOra Software. 1987. POLO-PC. A user's guide to probit analysis or logit analysis. LeOra Software, Berkeley, CA.

Mayo, Z B. 1986. Field evaluation of insecticides for control of larvae of corn rootworms, pp. 183-203. In J. L. Krysan and T. A. Miller [eds.], Methods for the study of pest Diabrotica. Springer, New York.

Meinke, L. J. 1995. Adult corn rootworm management. Univ. Nebr. Agric. Res. Div. Misc. Publ. 63.

Meinke, L. J., B. D. Siegfried, R. J. Wright, and L. D. Chandler. 1998. Adult susceptibility of Nebraska western corn rootworm populations to selected insecticides. J. Econ. Entomol. 91: 594-600.

Miota, F., M. E. Scharf, M. Ono, P. Marçon, L. J. Meinke, R. J. Wright, L. D. Chandler, and B. D. Siegfried. 1998. Mechanisms of methyl and ethyl parathion resistance in the western corn rootworm. Pestic. Biochem. Physiol. 61: 39-52.

Monke, B. J., Z B Mayo, and H. J. Ball. 1985. Bioassay rating system for predicting mortality of moribund corn rootworm (Coleoptera:Chrysomelidae) larvae following exposure to insecticide-treated soil. J. Econ. Entomol. 78: 467- 470 .

Monke, B. J., and Z B Mayo. 1990. Influence of edaphological factors on residual activity of selected insecticides in laboratory studies with emphasis on soil moisture and temperature. J. Econ. Entomol. 83: 226-233.

Robertson, J. L., and H. K. Preisler. 1992. Pesticide bioassays with arthropods. CRC, Boca Raton, FL.

Sammons, A. E., C. R. Edwards, L. W. Bledsoe, P. J. Boeve, and J. J. Stuart. 1997. Behavioral and feeding assays reveal a western corn rootworm variant that is attracted to soybeans. Environ. Entomol. 26: 1336-1342.

SAS Institute. 1985. SAS user's guide: statistics, 5 th ed. SAS Institute, Cary, NC.

Scharf, M. E., G. W. Bennett, B. L. Reid, and C. Qiu. 1995. Comparisons of three insecticide resistance detection methods for the German cockroach. J. Econ. Entomol. 88: $536-542$.

Scharf, M. E., L. J. Meinke, B. D. Siegfried, R. J. Wright, and L. D. Chandler. 1999. Carbaryl susceptibility, diagnostic concentration determination and synergism for U.S. populations of western corn rootworm. J. Econ. Entomol. 92: 33-39.

Siegfried, B. D., and C. A. Mullin. 1988. Properties of a cytochrome P-450-dependent epoxidase in aldrin-resistant western corn rootworms. Pestic. Biochem. Physiol. 31: 261-268.

Sutter, G. R. 1982. Comparative toxicity of insecticides for corn rootworm (Coleoptera:Chrysomelidae) larvae in a soil bioassay. J. Econ. Entomol. 75: 489-491.

Sutter, G. R., T. F. Branson, J. R. Fisher, and N. C. Elliot. 1991. Effect of insecticides on survival, development, fecundity and sex ratio in controlled infestations of western corn rootworms. J. Econ. Entomol. 84: 1905-1912.

Van Asperen, K. 1962. A study of housefly esterases by means of a sensitive colorimetric method. J. Insect Physiol. 8: 401-406.

Wright, R. J., L. J. Meinke, and B. D. Siegfried. 1996. Corn rootworm management and insecticide resistance management, pp. 45-53. In Proceedings of the 1996 Crop Protection Clinics. Cooperative Extension, University of Nebraska, Lincoln.

Received for publication 9 December 1998; accepted $10 \mathrm{Au}$ gust 1999. 